\title{
De blinde vlek van kieswijzers
}

\author{
Martin Rosema
}

Concept-versie van: Rosema, Martin (2017). De blinde vlek van kieswijzers. Beleid en Maatschappij, vol. 44, no. 1, pp. 95-97.

In de aanloop naar verkiezingen maken miljoenen mensen in Nederland gebruik van kieswijzers, zoals StemWijzer of Kieskompas. Bij de Tweede Kamerverkiezingen in 2012 waren er tientallen van zulke websites op het internet beschikbaar. Uit onderzoek is bekend dat ze twijfelende kiezers helpen om hun keuze te maken, waardoor de opkomst een paar procent wordt verhoogd. Verder is gebleken dat met name zwevende kiezers zich vaak door de uitkomst van een stemhulp laten leiden bij het bepalen van hun partijkeuze. Het is daarom van groot belang dat kieswijzers op een deugdelijke manier worden ontworpen. In de campagne worden daar steevast vraagtekens bij geplaatst. Zowel politieke partijen als kiezers hebben geregeld kritiek op kieswijzers en ook in het wetenschappelijke onderzoek naar hun ontwerp worden soms stevige noten gekraakt. Is die kritiek terecht en zo ja, hoe ernstig is deze? Is er een zó fundamentele tekortkoming dat we kunnen spreken van een blinde vlek?

De kritische opmerkingen die door kiezers vermoedelijk het meest worden gemaakt, betreffen de inhoud van het advies dat niet zou deugen. Sprekende voorbeelden zijn jongeren die onverwacht aan 50PLUS worden gekoppeld, of overtuigde atheïsten die volgens een kieswijzer bij de ChristenUnie zouden passen. Hoewel dergelijke uitkomsten niet voor de hand liggen, wil dat niet zeggen dat het advies niet klopt. Wanneer een niet-religieuze kiezer dezelfde standpunten heeft als de ChristenUnie over thema's als onderwijs, milieu, financiën, immigratie, gezondheidszorg en democratische vernieuwing, dan kan die partij wel degelijk het meest passend zijn. Maar natuurlijk staat het kiezers altijd vrij om zulke adviezen naast zich neer te leggen, omdat het religieuze karakter van de partij ze niet aanstaat, de lijsttrekker niet in de smaak valt, of welke andere reden dan ook. We moeten ons realiseren dat het doel van kieswijzers niet is om bestaande voorkeuren te voorspellen, maar om te beoordelen in welke mate kiezers het eens zijn met de standpunten van de politieke partijen. Wanneer kieswijzers bestaande voorkeuren altijd zouden onderschrijven, zouden ze hun waarde meteen verliezen.

Niet alleen kiezers plaatsen vaak vraagtekens bij kieswijzers, ook politieke partijen laten soms van zich horen. Politieke nieuwkomers zijn nogal eens ontstemd dat ze niet in een kieswijzer zijn opgenomen. Ook deze kritiek is niet overtuigend. Doorgaans worden alle partijen die in de Tweede Kamer zijn vertegenwoordigd opgenomen in kieswijzers, zelfs de kleinsten. Het is toch niet teveel gevraagd om als nieuwe politieke partij eerst aan te tonen dat je op eigen kracht ten minste één zetel in het parlement weet te bemachtigen, voordat de makers van kieswijzers je net zo serieus nemen als andere politieke partijen? De beslissing om niet alle nieuwe partijen meteen in een kieswijzer op te nemen is alleszins te billijken. Het hoeft dan ook niet te verbazen dat de rechter zulke nieuwe partijen nog nooit in het gelijk heeft gesteld in de zaken die door hen tegen de makers van stemhulpen zijn aangespannen.

Soms wordt de positie die een kieswijzer bij een specifieke stelling toekent aan een politieke partij in twijfel getrokken. Politieke partijen geven bijvoorbeeld aan dat ze het niet eens zijn met het standpunt dat aan hen bij een bepaald onderwerp wordt toegeschreven. Dat zou men kunnen ondervangen door 
de politieke partijen zelf te laten aangeven wat hun standpunt is, maar daar kleeft een groot nadeel aan. Politieke partijen zullen de ruimte kunnen gebruiken om hun daadwerkelijke standpunten soms te verhullen met als doel gunstiger voor de dag te komen bij de resultaten van een kieswijzer. CDAwoordvoerder Jack de Vries gaf na de verkiezingen al eens toe dat zijn partij de positionering van het CDA bij bepaalde stellingen had gemanipuleerd, omdat het wist dat het daadwerkelijke standpunt niet populair was. Andere partijen zullen op dat punt ook niet allemaal heilig zijn. De ontwerpers van kieswijzers hebben dus een eigen verantwoordelijkheid als het gaat om het vaststellen van de standpunten van politieke partijen, bijvoorbeeld op basis van verkiezingsprogramma's of stemgedrag in het verleden in de Tweede Kamer. Af en toe zal men daar best eens een steek laten vallen, maar het gaat hier eerder om kleine tekortkomingen dan fundamentele problemen.

Een andere vorm van kritiek betreft de selectie van stellingen van een kieswijzer, die nooit iedereen tevreden kan stellen. Het is niet vreemd dat de Partij voor de Dieren vindt dat een aantal stellingen over dierenwelzijn zou moeten gaan, terwijl de SGP een aantal morele keuzes op het gebied van het levenseinde of de zondagsrust zou willen opnemen. En zo zal elke partij eigen wensen hebben. Uit wetenschappelijk onderzoek is bekend dat de selectie van stellingen van invloed is het advies dat gebruikers krijgen en hoe vaak een bepaalde partij als beste uit de bus komt. De kracht van kieswijzers is dat ze een breed scala aan onderwerpen aan bod laat komen. Vanuit dat perspectief zijn kieswijzers die gericht zijn op een bepaalde doelgroep (bijvoorbeeld zelfstandige ondernemers) of een specifiek thema (bijvoorbeeld natuur- en milieubeleid) te eenzijdig. Het risico voor de democratie is dat de Kamerleden hun kiezers slecht vertegenwoordigen ten aanzien van de veelheid aan onderwerpen die in het parlement aan de orde komen. De meest populaire kieswijzers laten gelukkig altijd een breed scala aan verschillende onderwerpen aan bod komen, al zal altijd betwist kunnen worden of een andere selectie beter was geweest.

In het wetenschappelijke onderzoek naar het ontwerp van kieswijzers hebben andere aspecten de aandacht getrokken. Eén ervan is de rekenmethode die wordt gebruikt om de antwoorden op de stellingen in een advies om te zetten. Gebleken is dat deze een zeer sterke invloed heeft op het advies dat wordt gegeven. Vooral wanneer stemadviezen worden gebaseerd op zogeheten ruimtelijke modellen, zoals Kieskompas gebruikt, doen zich problemen voor. Vaak zal een kiezer het meer eens zijn met een andere partij dan die welke in het plaatje het meest dichtbij staat. Dat komt doordat de stellingen die aan kiezers worden voorgelegd zich niet goed laten terugbrengen tot één of twee ideologische dimensies.

Een ander punt van kritiek betreft de vermeende oppervlakkigheid van stemhulpen en de veronderstelling dat kiezers standpunten hebben over alle onderwerpen die erin aan bod komen. Zou het in een democratie niet moeten gaan over het uitwisselen van argumenten en pas innemen van een standpunt nadat men alle voor- en nadelen heeft laten bezinken? Het snel beantwoorden van een serie stellingen, zonder via een inhoudelijk debat kennis te vergaren over de waarden en belangen die in het geding zijn, zou op gespannen voet staan met kernprincipes van de democratie, of op zijn minste de zogeheten deliberatieve democratie. Men zou hier tegenin kunnen brengen dat verschillende kieswijzers wel degelijk de mogelijkheid bieden tot nadere inhoudelijke verdieping, omdat ze ook toegang bieden tot toelichtingen op de standpunten van de politieke partijen. Helaas maken de meeste kiezers van die mogelijkheden nauwelijks gebruik en mogen ontwerpers zichzelf dus de vraag stellen hoe ze een dergelijke verdieping beter kunnen stimuleren. 
Wetenschappelijke inzichten over de betekenis van democratie en de rol van verkiezingen brengen ook een andere tekortkoming van kieswijzers aan het licht. De functie van verkiezingen in het democratisch proces is tweeledig. Ten eerste dienen zij om machthebbers verantwoording te laten afleggen over hun gedrag in de voorbije periode. In de Nederlandse context gaat het dan niet alleen over de vertegenwoordiging van de politieke partijen in de Tweede Kamer, maar uiteraard ook over de regering. Tegelijkertijd vervullen verkiezingen een tweede functie, namelijk het verschaffen van een mandaat aan de politieke partijen voor de toekomst. Op basis daarvan kan een nieuwe regering worden gevormd en zijn haar besluiten gelegitimeerd zolang de steun van het parlement wordt verkregen.

In het stemlokaal wordt kiezers dus als het ware gevraagd om tegelijk achteruit én vooruit te kijken. Een kieswijzer die beide functies van verkiezingen tot zijn recht wil laten komen, zal dus in de selectie van stellingen voor een evenwichtige mix moeten zorgen van besluiten die in de voorbije regeerperiode zijn genomen en onderwerpen die relevant zijn voor de volgende regeerperiode. Bij de makers van kieswijzers lijkt dat besef veelal te ontbreken. De meeste stemhulpen richten hun blik vrijwel uitsluitend op de toekomst. Een uitzondering bestaat in de vorm van StemmenTracker, die gebaseerd is op politieke besluiten uit het verleden, maar in deze stemhulp ontbreekt dan weer de even relevante blik op de toekomst. Al sinds de introductie van de eerste StemWijzer op het internet in 1998 blijft het wachten op een goede stemhulp die aan beide functies tegelijk goed recht doet.

Kort samengevat kan men stellen dat veel van de kritiek op kieswijzers, zowel van kiezers als van politieke partijen, niet terecht is. Toch is er één fundamenteel bezwaar dat tegen vrijwel alle kieswijzers kan worden ingebracht. Ze zijn gefocust op de plannen van politieke partijen voor de toekomst en hebben geen oog voor het laten afleggen van verantwoording over de standpunten in de afgelopen regeerperiode, wat ook eeb belangrijke functie van verkiezingen is. Dat is de blinde vlek van kieswijzers.

Martin Rosema is als universitair docent politicologie verbonden aan de Universiteit Twente. Hij is gespecialiseerd in verkiezingen en referenda en deed onderzoek naar het ontwerp en de effecten van kieswijzers. 